\title{
The Everyday's Fabulous Beyond: Nonsense, Parable, and the Ethics of the Literary in Kafka and Wittgenstein
}

\begin{abstract}
Many complain that the words of the wise, time and again, are only parables, but inapplicable to daily life, which is all we have. When the wise man says, "Cross over," he does not mean that one should cross over to the other side, which one could still manage, after all, if the result of going that way made it worth it; he means some sort of fabulous Beyond, something we do not know, which he cannot designate more precisely either, and which therefore cannot help us here at all. All these parables really intend to say is only that the incomprehensible is incomprehensible, and that we knew already. But all that we have to struggle with everyday: that is a different matter.

Thereupon someone said: Why all this resistance? If you followed parables, you would become parables yourselves and with that free of your daily cares.

Another said: "I bet that is also a parable."

The first said: "You have won."

The second said: "But unfortunately only in parable."

The first said: "No, in reality; in parable you have lost."
\end{abstract}

-Franz Kafka, "On Parables"1

\footnotetext{
${ }^{1}$ My translation. Here is Kafka's original text:

"Von den Gleichnissen"

Viele beklagen sich, daß die Worte der Weisen immer wieder nur Gleichnisse seien, aber unverwendbar im täglichen Leben, und nur dieses allein haben wir. Wenn der Weise sagt: »Gehe hinüber«, so meint er nicht, daß man auf die andere Seite hinübergehen solle, was man immerhin noch leisten könnte, wenn das Ergebnis des Weges wert wäre, sondern er meint irgendein sagenhaftes Drüben, etwas, das wir nicht kennen, das auch von ihm nicht näher zu bezeichnen ist und das uns also hier gar nichts helfen kann. Alle diese Gleichnisse wollen eigentlich nur sagen, daß das Unfaßbare unfaßbar ist, und das haben wir gewußt. Aber das, womit wir uns jeden Tag abmühen, sind andere Dinge.

Darauf sagte einer: »Warum wehrt ihr euch? Würdet ihr den Gleichnissen folgen, dann wäret ihr selbst Gleichnisse geworden und damit schon der täglichen Mühe frei.»

Ein anderer sagte: »Ich wette, daß auch das ein Gleichnis ist."

Der erste sagte: »Du hast gewonnen.«

Der zweite sagte: »Aber leider nur im Gleichnis.«

Der erste sagte: »Nein, in Wirklichkeit; im Gleichnis hast du verloren«.
} 


\begin{abstract}
You won't-I really believe-get too much out of reading it. Because you won't understand it; the content will be strange to you. In reality, it isn't strange to you, for the point of the book is ethical. I once wanted to give a few words in the preface which are actually not in it, but which I'll write to you now because they might be a key for you: I wanted to write that my work consists of two parts: the one presented here plus all that I have not written. And it is precisely this second part that is the important one. My book draws limits to this sphere of the ethical only from inside as it were, and I am convinced that this is the ONLY rigorous way of drawing those limits. In short, I believe that where many others today are just babbling, I have managed in my book to put everything firmly into place by being silent about it.

$\mathrm{T}$ HIS ESSAY TAKES UP the significance of Wittgenstein's philosophy for our understanding of literature (and vice versa) through a comparative reading of the stakes and aims of Kafka's and Wittgenstein's circa-1922 puzzle texts "Von den Gleichnissen" ("On Parables") and the Tractatus Logico-Philosophicus. I examine the ethical weight of these two writers' shared investment in the philosophical depth of riddles, irony, and parabolic and nonsensical expression as unorthodox modes of indirect instruction about ordinary language and world, the yearning for transcendence and the failure to achieve it. My central aim in discussing Wittgenstein's Tractatus and "Lecture on Ethics" alongside Kafka's parable is to examine some of the ways in which Wittgenstein's philosophical outlook, writing, and method (shaped by his general attraction to the Book and book writing as well as by his reading of certain works of literature) are deeply relevant to studies in literature, and particularly to our understanding of literary modernism. ${ }^{3}$

But aside from Kafka's established position as an exemplary figure in the European modernist canon, why bring him into an effort to say something new about Wittgenstein and the relationship between his thought and literary modernism? Kafka is not known to have read Wittgenstein, nor was he one of the modernist figures Wittgenstein was known to have enjoyed. In fact, Wittgenstein's acquaintance with Kafka's writing was, at best, extremely limited. The more than 20,000

\footnotetext{
${ }^{2}$ For a quotation of the entire letter in English translation, see G.H. von Wright's "Historical Introduction" in Prototractatus 15-16. Here is Wittgenstein's original, excerpted from his Briefe and Ludwig von Ficker 35:
}

Von seiner Lektüre werden Sie nämlich—wie ich bestimmt glaube—nicht allzuviel haben. Denn Sie werden es nicht verstehen: der Stoff wird Ihnen ganz fremd erscheinen. In Wirklichkeit ist er Ihnen nicht fremd, denn der Sinn des Buches ist ein Ethischer. Ich wollte einmal in das Vorwort einen Satz geben, der nun tatsächlich nicht darin steht, den ich Ihnen aber jetzt schreibe, weil er Ihnen vielleicht ein Schlüssel sein wird: Ich wollte nämlich schreiben, mein Werk bestehe aus zwei Teilen: aus dem, der hir vorliegt, und aus alledem, was ich nicht geschrieben habe. Und gerade dieser zweite Teil ist der Wichtige. Es wird nämlich das Ethicsche durch mein Buch gleichsam von Innen her begrenzt; und ich bin überzeugt, daß es, streng NUR So zu begrenzen ist. Kurz, ich glaube: Alles das, was viele heute schwefeln, habe ich in meinem Buch festgelegt, in dem ich darüber schweige. Und darum wird das Buch, wenn ich mich nicht sehr irre, vieles sagen, was Sie selbst sagen wollen, aber Sie werden vielleicht sicht sehen, daß es darin gesagt ist. Ich würde Ihnen nun empfehlen, das Vorwort und den Schluß zu lessen, da diese den Sinn am Unmittelbarsten zum Ausdruck bringen.

${ }^{3}$ For different discussions of the relevance of Wittgenstein's Tractatus to our understanding of literature, and literary modernism in particular, see Perloff, North, Fischer, LeMahieu, Mulhall, and, especially, the essays collected by Gibson and Huemer. For an earlier discussion of the Tractatus and Kafka's work, see Bramann; for a more recent discussion see Schuman. Both Sokel and Corngold offer excellent readings of Kafka's late parable in their own treatments of Kafka's unique exploration of gnostic spiritual yearning in the context of a modernist everyday. 
pages of Wittgenstein's unpublished writings contain no mention of Kafka, and the only recorded testimony of his having read Kafka at all survives in the form of a humorous anecdote related by the philosopher Elizabeth Anscombe. While a student of Wittgenstein's, she lent him The Trial and a collection of stories in an effort to share with him her enthusiasm about Kafka's writing. Upon returning the books to her in rather short order, Wittgenstein quipped: "This man gives himself a great deal of trouble not writing about his trouble." He recommended that she read instead Otto Weininger, a man who, he assured her, really did write about his trouble (Monk 498).

A thorough unpacking of the implications of Wittgenstein's loaded yet rather inscrutable comment so as to understand more fully the relationship of his thought to Weininger's writing (and indeed, troubles) would call for a different discussion entirely (see, for example, Stern and Szabados). ${ }^{4}$ My choice to invoke the reported remark at the outset of this essay is inspired not so much by its undeniable epigrammatic qualities as by a relevance to the current discussion that exceeds the merely ornamental. After all, if Kafka is a man who gives himself troubles not writing about his troubles, what of Wittgenstein, the man who troubles to confront the "problems of philosophy" and to disabuse his readers of their philosophical and personal confusions by simultaneously mesmerizing and perplexing them with an enigmatic book the constituent propositions of which he declares at the end to be "simply nonsense" and which opens and closes with the famous dictum "Wovon man nicht sprechen kann, darüber muß man schweigen" - what we cannot speak about we must be silent about (Tractatus p. 3 and $\S \S 6.54-7)$ ?

Both Wittgenstein and Kafka are men who go to quite a lot of trouble not writing (at least not directly) about their troubles, the problems they grapple with and prompt their readers to grapple with in turn. Indeed, the poetic and philosophical force of the two texts I examine here ironically depends upon the very method that Wittgenstein curmudgeonly criticizes in Kafka's work. "On Parables" and the Tractatus are texts whose philosophical or ethical points are made through what is not in them, rather than through anything they say explicitly. In Cora Diamond's terms, both texts are marked by absence. Both leave it up to their readers to figure out how to learn something from that absence (of answers, explanations, resolution, or straightforward teaching) by turning it into some-

\footnotetext{
${ }^{4}$ My discussion of Wittgenstein's Tractatus is indebted to a body of secondary literature that puts forth a "resolute" program of reading the Tractatus. Resolute readings offer accounts of how the Tractatus's peculiar method and structure serve its therapeutic ethical aim, locating the instructive force of the book not in its attempt to put forth metaphysical doctrines about the way language relates the world, but in the ethical aim of effecting a shift in its readers' world view. The resolute program insists that readers take seriously Wittgenstein's claim that the propositions that make up the body of the text amount to nothing more than nonsense to be thrown away once they have served their elucidatory purpose. The body of the Tractatus, according to resolute readings, represents an elaborate mock-doctrine Wittgenstein self-consciously employs in an attempt to display to his readers the confusion that plagues them. Although the number of proponents of this general line of interpretation has grown steadily in recent years, for relevance to the specific concerns of this essay, see especially Diamond, The Realistic Spirit, "Ethics, Imagination and the Method of Wittgenstein's Tractatus," and "Wittgenstein and Religious Belief"; Conant, "Throwing Away the Top of the Ladder," "Must We Show What We Cannot Say?," "Putting Two and Two Together," "What 'Ethics' in the Tractatus is Not," and "Mild Mono-Wittgensteinianism"; Conant and Diamond, "On Reading the Tractatus Resolutely" and Rileggere Wittgenstein (with an introduction by Piergiorgio Donatelli and afterword by Silver Bronzo); Crary and Read; Friedlander; Donatelli; Read and Lavery; and Cahill.
} 
thing that transforms our understanding of the problems and mysteries of language and life ("Introduction" 127-31). What Eli Friedlander says of Wittgenstein's Tractatus also provides us with an apt description of Kafka's parable, since each of these works "perspicuously represents an empty place" of non-meaning we must come to recognize in the midst of our search for meaning. Each performs the intrinsically contradictory task of succeeding in its aim "only by bringing us close to the failure or disintegration of language in such a way as to illuminate or provide an elucidation" (152).

I opened this essay with two epigrams. The first is Kafka's short parable, the second an excerpt from a letter Wittgenstein sent to Ludwig von Ficker, publisher of the Austrian literary journal Der Brenner, which the philosopher saw as a potential home for the Tractatus, a text he described as "strictly philosophical and at the same time literary” (Briefe 33). Kafka's philosophically demanding meta-parable depicts an exchange between a set of interlocutors who vocalize (in a manner reminiscent of the conversations of the Philosophical Investigations) conflicting viewpoints about figurative language and its bearing — or failure to bear - on the realities of everyday life. It is a parable with two parts. The first sets out the problem in question: the apparent incommensurability between the mystical words of the "wise" and the unknown "fabulous Beyond" they profess to address, on the one hand, and the concrete language and "things we struggle with every day," on the other. The second is dedicated to a jousting interpersonal exchange that serves as a Kafkan exegesis (depending in part on the parody of exegesis) of the problem outlined in the first. The parable as a whole offers no clearly stated lesson or particular message. Both Joshua Landy and Frank Kermode point out that parables (Kafka's included, I would argue) seek to challenge and train us as by requiring a certain kind of interpretive philosophical and literary work that we must also incorporate into the way we think and live our lives. What Cora Diamond says, in a similar vein, of Wittgenstein's Tractatus also applies to Kafka's parable: "The book doesn't 'teach' one philosophy, in the sense that it has no teachings on offer; and as long as one restricts oneself to looking for teachings, one will be unable to learn anything philosophical from it" ("Introduction" 128).

"On Parables" opens up a space for readers to continue the exegetical work performed within it by adding further interpretations to the debate. The impulse to add to the parable's last line our own "I bet that is also a parable" signals the bewildering and possibly unending interpretive task that this layered piece demands of its readers. This same inclination to redeploy that riposte with a greater imaginative insight on a critical meta-level in order thereby to rise to the parable's challenge (by rising above the failure of its internal voices to identify and put to rest the questions it raises with something wiser than a wisecrack) also speaks to the important way the parable plays upon the hubris and performance anxiety of readers who long to be "in on" the joke and are eager to follow its parabolic movement toward a deeper understanding we worry may entirely elude us. James Conant and Michael Kremer emphasize an oscillation between arrogance and a fear of failure that readers of the Tractatus share with the readers of Kafka's parable (Conant, "Must We Show"; Kremer). Eager to become part of the apparently select readership that will find pleasure in the Tractatus by approaching it "with understanding," as Wittgenstein says in the preface, we wonder whether we are up to the challenge. 
Seeing Kafka's parable as a two-part piece also helps us to recognize something crucial about the interpretive demands it makes of its readers. Understanding what the parable has to teach us depends upon our ability to pay careful attention to the ways in which the point of the parable emerges, unstated, from a gap between the two extremes of experience it depicts: everyday facticity, on the one hand, and a fictive and fantastic pure transcendence (represented by the calls to "cross over" to the fabulous beyond and to "become parables"), on the other. In part, Kafka negotiates the tension between these two extremes by playing on the linguistic and generic conventions of parable, prophetic pronouncement and witty gaming repartee, blurring the modes of communication appropriate to each and exploiting our expectations about tone, timing, delivery, and conclusion. The parable, which culminates in a dual gesture of interpretive fallibility and transformative promise, represents the kind of disquieting "grammatical joke" that Wittgenstein describes as having the character of significance that gets at the very depth of philosophy (PI $\$ 111)$.

Wittgenstein's Tractatus, for its part, is an elaborate two-part puzzle text that functions as an aesthetic medium for its author's unique brand of indirect instruction. The book turns out not to be the straightforward logical-philosophical tract it first appears to be, but a mock doctrine to be cast aside once it has served what its author claims is its "elucidatory" transformative purpose: getting its readers to "see the world in the right way" (Tractatus $§ 6.54$ ). Wittgenstein himself maintained that this purported treatise on philosophical logic (which also deals with "the mystical," value, and transcendence; entails brief first-person confession, prophetic pronouncement, and sudden epiphanic insight; and addresses the "problem of the meaning of life" before culminating in the religious figure of a ladder in a final gesture at closure as illusory as it is profoundly relevatory) is really a book about ethics. To complicate things further, Wittgenstein insisted that, although the aim of the book is an ethical one, the ethical "part" of the book - the only part that truly matters - is the part that appears nowhere among its spare aphorisms.

The distinguishing formal features and transformative pedagogy of the Tractatus all play a role in the ethical aim of the book. This aim involves leading us out of our philosophical complacency and delivering us from the confusions in which we become entangled while philosophizing (confusions such as the idea that there are limits of language and thought to which we can restrict ourselves or go beyond, the idea that there is such a thing as an external point of view from which to survey language and thought, and so on) by engaging us in a process that culminates (at least ideally) in an enlightened understanding and clear vision of the world, life, philosophy, and language (all of which he sees as interdependent parts of the same endeavor). The Tractatus lures us into a mock metaphysical theory in order to explode that theory from within by showing us that the sentences that have seduced us into the illusion that they make sense or that we can do philosophy in a traditional vein amount to nothing more than nonsense.

If a central aim of the Tractatus is to disabuse us of our tendency to utter nonsense born of metaphysical confusion, in his "Lecture on Ethics" Wittgenstein explicitly claims that all our attempts to give expression to our ethical or spiritual experience of the world are essentially nonsensical - the product of a yearning to "go beyond the world and ... significant language" by giving in to the "tendency to ... write or talk Ethics or Religion." Yet this tendency to utter nonsense is not 
something we should work to overcome (as we are to do with our tendency to come out with metaphysical propositions according to the "strictly correct" method in philosophy he outlines in Tractatus §6.53). Wittgenstein emphasizes instead that there is something deeply important about this tendency: although "Ethics so far as it springs from the desire to say something about the ultimate meaning of life, the absolute good, the absolute valuable ... does not add to our knowledge in any sense," it nonetheless provides us with "a document of a tendency in the human mind" that he "cannot help respecting deeply" ("Lecture" 44).

In a conversation with members of the Vienna Circle recorded by Friedrich Waismann, Wittgenstein brings both Heideggerian dread and Kierkegaardian paradox to bear on his discussion of attempts to talk about ethical experience, attempts that he describes repeatedly and metaphorically as the "impulse to run up against the limits of language":

In Ethics one is always making the attempt to say something that does not concern the essence of the matter and Never can concern it. It is a priori certain that whatever one might offer as a definition of the Good, it is always simply a misunderstanding to think that it corresponds in expression to the authentic matter one actually means (Moore). Yet the tendency represented by the runningup-against points to something. St. Augustine already knew this when he said: What, you wretch, so you want to avoid talking nonsense? Talk some nonsense, it makes no difference! (Ludwig Wittgenstein and the Vienna Circle 69)

One important starting point for an account of Wittgenstein's relevance to literary studies (in the absence of any clearly stated Wittgensteinian literary program) is to be found in Wittgenstein's claims that our attempts to give voice to the experience of what we take to be ethically or spiritually significant (a category that would seem to include some, if not all, literary endeavors) will necessarily result in nonsense that arises from a tendency that Wittgenstein says points to something and which he confesses to respecting deeply. A second point of departure lies in the relationship between his early view about the essential nonsense of "ethical" sentences and his tendency (deliberately demonstrative of our own) to turn repeatedly to figurative language and literary example in his effort to put forth this view.

However, Wittgenstein's use of figurative language in his discussion of nonsense and ethics is complicated by his claim that, although ethical and religious language tends inherently toward metaphor and simile, these are but empty figures that necessarily miss the mark. What we vainly attempt to say when we use such language escapes signification because such attempts endeavor, in Eli Friedlander's words, to "present the transcendence of absolute value by means of something that can be said, a fact" (141). As Wittgenstein puts it:

Thus in ethical and religious language we seem constantly to be using similes. But a simile must be the simile for something. And if I can describe a fact by means of a simile I must also be able to drop the simile and to describe the facts without it. Now in our case as soon as we try to drop the simile and simply to state the facts which stand behind it, we find that there are no such facts. And so, what at first appeared to be a simile now seems to be mere nonsense. ("Lecture" 42-43)

The normal tropological movement between what is said and what is meant does not apply in such cases because there is no literal meaning to which ethical language can correspond. Our sentences about ethics represent a desire to signify that is necessarily bound up with a failure to signify. Saying what we mean to say when we talk about significant experience, then, necessarily depends on saying things that, strictly speaking, make no sense at all. 
Diamond and Friedlander both take up the question of the literary dimension of Wittgenstein's philosophy by focusing on Wittgenstein's investment in the Book in his early writing. Wittgenstein mentions two books in the Tractatus: the work itself and the imagined The World as I found It. In the "Lecture on Ethics" he adds two more books that present a view of a great beyond: the fantastical "big book" that contains "the whole description of the world" written by an "omniscient person," which presents us with the sum total of "facts, facts and facts but no Ethics," and its opposite, the apocalyptic book of pure transcendence:

. . if I contemplate what Ethics really would have to be if there were such a science, this result
seems to me quite obvious. It seems to me obvious that nothing we could ever think or say would be
the thing. That we cannot write a scientific book, the subject matter of which could be intrinsically
sublime and above all other subject matters. I can only describe my feeling by the metaphor, that, if
a man could write a book on Ethics which really was a book on Ethics, this book would, with an
explosion, destroy all the other books in the world. ("Lecture" 40)

The Tractatus, as Friedlander sees it, is stretched between the opposing temptations these two "impossible" books exemplify: that of pure fact and that of pure transcendence (12-15). Giving into the first temptation leads us to see the book as concerned essentially with the possibility of language to picture facts. Giving in to the second is to see the whole point of the book as a mystical grasp of a transcendent source of value outside the world. The Tractatus occupies the gap between both extremes. Its primary aim is to open us to our own experience-as revealed through everyday language - by leading us beyond the dichotomy of facticity and transcendence, away from the urge to transcend the limits of language and toward a recognition that our ordinary dealing with things has a significance that is at once linguistically meaningful and ethically valuable (17).

Wittgenstein's complex project in the Tractatus can thus give us a new critical language for articulating the literary and philosophical stakes of Kafka's parable (in which the dichotomy between facticity and transcendence, struggles with mythical limits of language, and the yearning to find meaning beyond them are also central). Reading "On Parables" in light of Wittgenstein's mock-doctrinal early work, with its therapeutic aim, also prompts us to recognize the mock-parabolic and diagnostic (though never curative) aspects of Kafka's short piece. Likewise, looking at the Tractatus with Kafka's parable in mind leads to new ways of understanding the role that Wittgenstein's interest in figurative language plays in the book. More broadly, this suggests that looking at these two circa-1922 works in relation to each other calls upon us to account for their shared and respective contributions to a discursive convergence of early twentieth-century writers responding to the complexity of modern life and the cataclysm of war with an urgent attention to difficulty that brings them back to the very oldest riddles (the meaning of life, problems of the self and other minds, the possibility of redemptive change, the contrast between how things are in the world and their significance from the point of view of the "higher"). Both Kafka's and Wittgenstein's works speak to what I take to be a definitive aspect of secular modernism: an attraction to mystery and transcendent experience manifested in an obsession with the transformative power of puzzles, riddles, unanswered - and often unanswerable-questions, and quests for their solutions. Wittgenstein's and Kafka's explorations of language, text, and meaning are marked by a distinctly modernist preoccupation with a combination of hope, loss, possibility, and failure. They are rooted in the 
concrete world, trying to make sense of it through literature with a philosophical bent (Kafka) and philosophy (which Wittgenstein claimed really ought to be "poeted") that depicts a straining (within ordinary language and life) for an ineffable Beyond.

\section{Gleichnis and Likeness}

The "Gleichnis" of Kafka's title not only means "parable" and "similarity" but also points to figurative and poetic language in general. Wittgenstein was almost certainly thinking of the broader meaning of "Gleichnis" when he used the English word "simile" in his discussion of ethical expressions in the "Lecture on Ethics." Given the importance of "Gleichnis" to both writers' thought, it is helpful to examine some further salient likenesses between Wittgenstein's and Kafka's works.

Kafka's depiction of different levels of mundane, spiritual, and literary understanding offers us valuable insights into the kind of interpretive engagement a text like the Tractatus demands, since the parable (like the "treatise") deals internally with the decisive difference between a reader's imaginatively "getting" the philosophical import of a story (or riddle, or joke) and not getting it, between a reader's ability to engage imaginatively and ethically with a text— to make of it something from which philosophy can be learned - or not (Diamond, "Introduction" 128; "Ethics and Imagination" 157). It also points to the difference between the person who tries to see from the perspective of the utterer of nonsense or the teller of parables and the person who sees such a world view as utterly foreign. Kafka's delineation of this difference, like Wittgenstein's, turns on an examination of the relationship (or lack thereof) between the activities and difficulties of everyday life and those of literary expression and/or spiritual or philosophical teaching. The Tractatus and "On Parables" both implicitly critique doctrines that would posit an unbridgeable divide between ordinary language and world and what lies beyond their mythical limits.

Wittgenstein's and Kafka's puzzles entail an interpretive challenge that is coincident with the aim Wittgenstein saw as ethical. Each draws upon the power of literature and philosophy in order to lead us to transform our attitude toward everyday language and life and also to shift our views about the kind of work that literature and philosophy can do. Although both texts call for a change in attitude toward language and the world that allows us to see problems more clearly, both are designed to call into question the status, value, and even the hope of our ever arriving at solutions to those problems. Both defy our attempts to sum them up neatly; neither offers us the final answer they seem to strive after and that we crave. Furthermore, each of these works ultimately is dedicated to disabusing us of the misconception that there is any such thing as a single "correct" method for attaining philosophical, personal, or linguistic clarity, just as there is no particular ethical "part" of the Tractatus or important something or place that lies beyond sensible language toward which philosophy and literature can gesture ineffectually.

Both Wittgenstein and Kafka repudiate explanation, doctrine, and dogmatic thinking, while simultaneously recalling the structure and prophetic tone of narratives of spiritual instruction and conversion as a way of exploring a human 
yearning for truth and what Wittgenstein calls "wonder," a yearning that motivates our attempts to account for mystery through the construction of doctrine. Due to their mock-doctrinal aspects, both texts are also characterized by a disjunction between what we thought they were getting at and what they end up leaving us with. Wittgenstein claimed he sought not to teach us new truths but to give us a method for seeing more clearly the language and world we already know. Kafka turned to parables not to clarify any particular Truth, but to explore different ways in which the truths to which modern humanity must submit can be transmitted, turned around, and looked at in different ways.

In the preface to the Tractatus, Wittgenstein states that the purpose of his perplexing book would be achieved if it gave pleasure to the person who reads it "with understanding." If Wittgenstein frequently speaks of a division between those who will understand the book and those who will not (in claims that would seem to posit a rift not unlike the one Kafka's speaker sets up in his parable), he also suggests in the letter to von Ficker that, in spite of its difficulty, the Tractatus is addressed, as Diamond puts it, to the ordinary person's understanding rather than to his ignorance ("Ethics and Imagination" 149). Wittgenstein assures von Ficker that while the book will surely seem fremd (strange, foreign), it has much to say that von Ficker would like to say himself, although he may not immediately notice that it has been said. What is difficult about texts like Wittgenstein's and Kafka's has less to do with their content than with the challenge of getting readers to change their mode of approach to the enigmas the texts present in such a way that they come to see and experience differently.

\section{Kafka's "On Parables," Wittgenstein's "Lecture on Ethics," Nonsense and Secondary Sense}

In "On Parables" Kafka offers a treatment of nonsense, tautology, understanding, and transformative yearning in his own brand of literary-philosophical puzzle. In the first part of the piece Kafka's speaker gestures at (and holds at a narrative distance in a ventriloquizing frame) a vague, complaining "many," who deem the parables of the wise inapplicable to the realities of daily life. In their view, the wise man's command that we cross over into an elusive "fabulous Beyond" offers an unhelpful directive since it fails to designate any (literal) place to which we (literally) should go. Although its lofty poetic tone or promise of deliverance may hold an attraction for some, the command hardly amounts to a practical prescription for the problems that plague us "here." What's more, strictly speaking, such parabolic commands make no sense at all. All that parables do, according to the point of view Kafka's speaker vocalizes, is resort to figurative language that tells us nothing we do not already know. Attempts to explain the meaning of a parable, then, inevitably lead to tautologies like "the incomprehensible is incomprehensible," the very sort of senseless tautologies Wittgenstein uses in the Tractatus. The words of the wise do nothing to explain, let alone offer us salvation from, the difficulties of the human condition.

I emphasize Kafka's phrase "cross over" here because it resonates with what Wittgenstein says in his "Lecture on Ethics" about the inherent nonsensicality of ethical or religious statements. Words that traditionally have been understood 
to have an ethical import ("good," "right," "valuable"), Wittgenstein tells us there, can be used in either a "relative" or an "ethical" sense. When we use them in a relative sense, we assign to the object they modify value that is always relative to some pre-established standard or purpose. For example, in a statement such as "This is the right road to Grantchester," we can explain the use of the word "right" by identifying the facts that led us to make this judgment-stating, perhaps, that a certain route is "the right road" to Grantchester because it is the road that gets us there most efficiently ("Lecture" 39).

But such value words can also be used very differently in sentences that make no reference whatsoever to any fixed purpose or standard. When such words are used in an "ethical" sense, when they are used, as Kafka's sage uses them, in parabolic religious statements and imperatives like "cross over" (i.e., to "the right road"), they are used in a context in which they have no predetermined logico-linguistic role. In Wittgenstein's view, when we say that someone ought to get on "the right road," we cannot explain what it is we want to say by an appeal to facts. "Our words used as we use them in science," he claims, "are vessels capable only of containing and conveying meaning and sense, natural meaning and sense. Ethics, if it is anything, is supernatural and our words will only express facts; as a teacup will only hold a teacup full of water even if I were to pour out a gallon over it" (40). All our attempts to put ethics into words will in the end only be vain attempts to "go beyond the world and ... run against the boundaries of language." As a result, Wittgenstein insists in the "Lecture" that nothing that makes sense could ever manage to get at what he is trying to say in his attempts to give voice to the experiences he takes to be ethical. Imagining attempts to resolve the paradox "that an experience, a fact, should seem to have supernatural value" with the suggestion that "what we mean by saying that an experience has absolute value is just a fact like other facts and that all it comes to is that we have not yet succeeded in finding the correct logical analysis of what we mean by our ethical and religious expressions" (44), he concludes: "Now when this is urged against me I at once see clearly, as it were in a flash of light, not only that no description that I can think of would do to describe what I mean by absolute value, but that I would reject every significant description that anybody could possibly suggest, ab initio, on the ground of its significance" (44). For Wittgenstein, expressions of ethical experience are nonsensical not because we have not yet found the correct ways of articulating them, but because their nonsensicality is their very essence. And we depend upon this nonsensicality in our attempts to say what it is we want to say when we talk about what we take to be ethically or spiritually significant. Nonsensicality is not only the essence of expressions of ethical and religious experience; it is also a vital force behind the poignancy of what we might call "ethical" expressions in the modes and genres, literary or otherwise, in which we choose to give voice to our sense of it. This point lies at the heart of Wittgenstein's claim that ethics includes "the most essential part of what is generally called Aesthetics" (38).

The Tractatus represents Wittgenstein's attempt to curtail our investment in metaphysical nonsense (as well as our tendency to spout it in philosophical theories and metaphysical propositions). As we have seen, however, Wittgenstein's position on the nonsense of ethical sentences does not mean that he would have us renounce all urges to express in words our ethical, religious, or poetical experience simply because these expressions are nonsense. And there is an impor- 
tant difference for Wittgenstein between the self-conscious nonsense- the nonsense of the Tractatus-intended to lead someone out of an attachment to unexamined nonsense and that un-examined nonsense itself. The difference is not one of category but of use.

Wittgenstein offers several paradigmatic examples of the kind of experience we feel inclined to describe as having ethical significance. His example par excellence is "wonder at the existence of the world" (41), an experience that may make us want to utter sentences like "how extraordinary that anything should exist" (41). Expressions of wonder at the world, he tells us, are not expressions of a desire to know the scientific explanations for the world's existence. They are expressions of our astonishment at the world's being "whatever it is" (42). But, as Wittgenstein explains, expressing wonder at the existence of the world is like saying "how wonderful that the world is the world" or - to return to Kafka's parable for a momentexpressing wonder at a tautology like "the incomprehensible is incomprehensible." But to express wonder at a tautology is simply nonsense (42). We are given to saying such things when the world strikes us as somehow strangely miraculous, for "the scientific way of looking at a fact is not the way to look at it as a miracle" (43). To regard the experience of wonder at the existence of the world as we would a scientific fact is to fail to grasp what Wittgenstein takes to be the ethical import of such an experience. Inseparable from our experience of the world as miraculous is the recognition that there can be no explanation for such a miracle; indeed, that a miracle cannot be explained is part of what makes it a miracle. Once a miracle has been scientifically explained, Wittgenstein asks, "where would the miracle have got to?" (43).

Attempts to give verbal expression to experiences that have ethical or religious value for us give rise to what Wittgenstein calls a "characteristic misuse of our language" (41). When we make ethical or religious use of phrases like Kafka's "cross over," he tells us, we might be tempted to think that we are using them as similes or Gleichnisse-as figurative stand-ins for some particular something we want to talk about. However, because there are no worldly facts standing behind them, the ethical use of these words is not metaphorical (or it ceases to serve that purpose); it is nonsense expressive of a yearning he takes quite seriously. Wittgenstein's discussion of the inexpressibility of ethics in the Tractatus and in the "Lecture on Ethics" is ultimately an attempt to show us something about the odd kind of linguistic intention we have when we feel moved, as he says (once again using nonsense masquerading as metaphor), to "go beyond the world" and utter ethical sentences (44). Our desire to say what we want to say when we feel so moved would only by thwarted if, in an attempt to refrain from uttering nonsense, we tried to limit all our talk to empirical descriptions. Although such ethical talk is inherently nonsensical, it nevertheless plays an important role in our lives, allowing us to express what no empirically meaningful sentence ever could.

Wittgenstein explores this kind of complex linguistic intention in his remarks on what he calls "secondary sense" in Part 2 of the Investigations (see Diamond, "Secondary Sense"). Here, Wittgenstein discusses the inclination to describe peculiar experiences by saying things like "for me the vowel $e$ is yellow" or "Wednesday is fat and Tuesday lean" (Investigations 202, 216). When a person utters a sentence like "the vowel $e$ is yellow," though he may call attention to the 
oddity of the sentence with qualifying framing remarks, he is not, according to Wittgenstein, using the word "yellow" in a non-literal or extended sense. "The secondary sense is not a 'metaphorical' sense," Wittgenstein writes. "If I say, 'For me the vowel $e$ is yellow,' I don't mean: 'yellow' in a metaphorical sense, -for I could not express what I want to say in any other way than by means of the idea 'yellow'" (216). The sentence could of course be made into a logically meaningful one if we gave a new meaning to "yellow" for all occurrences of the word as an adjective applied to vowels or sounds. But when we want to express ourselves in a certain way by saying things like " $e$ is yellow," giving the word a new meaning is precisely what we do not want to do: "I want to use these words (with their familiar meanings) here" (216). In cases like these, saying just what we want to say demands using words like "yellow" outside the contexts in which they have a fixed meaning. Were we to try to rectify the situation by turning a sentence involving ethical nonsense or secondary sense into a determinate meaningful proposition, that sentence would, by virtue of its very meaningfulness, fail to match the kind of complex linguistic intention it expresses.

If Wittgenstein composed the Tractatus in an effort to lead us toward recognizing our tendency to find confused metaphysical positions or sentences attractive, in the "Lecture on Ethics" he states that the impulse to utter patent nonsense to talk about the ethical significance of the world is something he does not want to criticize (44). In his view, our attraction to ethical sentences is not something that deeper self-understanding can or should make disappear. Nor is ethics a limited sphere of philosophical discourse among others. Like logic, ethics penetrates all thought and language. It is not something that one can meaningfully describe. The ethical, which is at one with aesthetics for Wittgenstein, shows itself in our humor, literature, music, art, and - not least of all-in ordinary language. The Tractatus is Wittgenstein's attempt to show that philosophical works also have the capacity to express ethical experience in this way, even though he claims that there is nothing said, strictly speaking, within the body of the text. We will not find an ethical theory in the nonsensical sentences of the Tractatus. Its ethics reside in the clarifying activity in which it is engaged and toward which he hopes to point his readers.

\section{Gleichnis and Nonsense}

Up to a point, Kafka's parable shares this aim, since it also seeks to engage its readers in the work of adopting different ways of seeing the world through riddling and attention to language that Wittgenstein would call nonsense. As I have argued above, Kafka's and Wittgenstein's works span the tension between the pure facticity and pure transcendence represented by the opposing impossible books of Wittgenstein's thought experiments. But while both authors make it their business to call our attention to the pitfalls of inclining toward either extreme, both nonetheless betray their investment in the power of figurative expressions of our longing for transcendence to give voice to our experience of the extraordinary within the ordinary. I take the thrust of Kafka's "On Parables" to be that parables and literary or otherwise figurative uses of language are relevant to daily life (not that their lessons are easily understood) and that "crossing over" (by adopting an attitude that allows us to enter imaginatively) into a 
"realm" where literary or religious language might enliven our daily lives is indeed worth it. But "On Parables" also complicates this picture, calling into question the effectiveness of such an aim and the promise of the process it seeks to set in motion as well as our ability actually to take it up. "On Parables" also seems to critique the implicit call for transformation we find within Kafka's own work, as well as Wittgenstein's.

When Kafka's wise man says "Cross over," he is making use of the kind of ethical or religious expressions Wittgenstein discusses in order to direct his listeners to the "right" road toward an enriched poetic and spiritual world view. As Kafka's speaker says, the sage certainly doesn't mean that we should cross to some actual place that we can designate ostensively. The "location" he is gesturing at is a place beyond the world and sensical language, as it were. Kafka's framing of the discussion that unfolds through the voices of the speaker from the first part and the sage and two interlocutors from the second part allows him to explore not only the different planes of understanding that are the parable's most obvious issue, but also the more subtle questions of levels of engagement with the unconscious, self-conscious, and ethical nonsense Wittgenstein would have us recognize. The spiritual command of Kafka's sage is nonsense in just the way that Wittgenstein sees all ethical, religious (and by extension, poetic and literary) language to be nonsense.

The lesson Kafka's sage wants to convey with his talk of crossing over to "some sort of Fabulous Beyond," the speaker recognizes, can only be expressed if the sage eschews straightforward meaning and cannot "designate more precisely" what he means and wants to say. Utterances like his reveal a complex linguistic intention that cannot be fulfilled by employing a more "precise" sentence that makes full logical sense. What the sage is saying renders strange the relationship between the literal and figurative and proves resistant to interpretations that seek to reformulate his command in straightforwardly factual terms. What Kafka's sage (and in turn the narrator who quotes him to his own purposes) is saying about everyday reality thus depends upon literary language - a language that paradoxically gestures not at reality but at a fabulous space beyond ordinary language and world.

In order to understand lessons imparted through nonsense used as a way of expressing ethical significance, the listener must be able to enter imaginatively into the speaker's particular kind of nonsense (Diamond, "Ethics and Imagination" 157). And this is precisely what the complaining "many" of Kafka's parable do not do. They cannot entertain the lessons the "wise men" want to teach about the incomprehensible because they do not adopt the imaginative perspective that a deep understanding of their gist would require. In the exchange that takes place in the second (exegetical) part of "On Parables," Kafka further develops his characterization both of a reader or listener oblivious to the complexities of the indirect moral lessons of parables and a second person who at least tries directly - rather than through instructive indirection - to tell others that they should give themselves over to their instructive sway). The exchange between the two interlocutors is initiated by "a man," who, making a sage pronouncement (or perhaps mocking such a pronouncement), intones: "If you were to follow parables, you would become parables and with that free of all your daily cares." 
This injunction to "become parables" represents either a literary platitude or yet another example of a nonsensical sentence expressive of a strange linguistic intention conveyed through the use of the secondary sense of a word, in this case "parable." This first man, having examined the first half of Kafka's parable-within-aparable, is eager to indulge (in a tongue-in-cheek manner at the very least) the imaginary possibility of giving himself over, so to speak, to a life led parabolically. But the meaning of such a suggestion remains unclear. For in what would "becoming parables" consist? A person imaginatively inclined toward literary, fictive, and figurative modes of describing the world might take such a statement in stride, but such a pronouncement seems unlikely to convince the unconvinced. Thus, the first man's approach will likely fail as a therapeutic curative aimed at getting people to overcome their resistance to seeing the importance of parables to ordinary life. Like the wise man in the first part, whose ethical nonsense is not used in such a way that the "many" can understand him (in the way Wittgenstein the utterer of nonsense asks us to understand him, rather than his sentences, in the Tractatus), the spokesman for parabolic conversion also fails to elicit the understanding of his interlocutors or readers with his ethical nonsense (Tractatus 6.54). The man who in the second part of the parable suggests that were we to follow parables we would ourselves become parables and rid of our daily cares either sets up a relation between parable and reality that demands a literal interpretation that leads to paradox (once Gleichnis becomes reality, where will the Gleichnis have got to?) or urges us parabolically toward a kind of death (literal or figurative) that will free us from our daily troubles. Neither one succeeds in bridging the gap between concrete world and figurative word in order to fulfill the yearning to bring the extraordinary to bear on the ordinary that seems to underlie the parable as a whole.

The first man's interlocutor responds to his suggestion with a gesture of oneupmanship: "I bet that's also a parable," he parries. To this claim, the first man concedes, "You have won." "But unfortunately only in parable," the second retorts. The second man's responses to the words of his interlocutor (and opponent, in what has now become a game) demonstrate both the competitive nature of his particular "A-HA Erlebnis" and his expertise in designating the outward linguistic and generic form of the first man's utterance. However, if what he says represents a momentary interpretive victory, it also demonstrates a far deeper failure to grasp the hermeneutic value of the lessons Kafka's parable would have us grasp. In parable he has lost. But, then, perhaps so has the first man, who has failed to help the second to see things in a way that would lead him to "win" by grasping the full value of parable.

In spite of the fact that the first man gets the last word in providing the apparent punch line, however, "On Parables" ultimately takes its place in a long history of Jewish parables, conundrums, and jokes without a clear moral or solution. Indeed, the seductive appeal of Kafka's text lies in the way it provokes our engagement in interpretation while at the same time thwarting it. As Walter Sokel has pointed out, Kafka's work lures us toward metaphysics and theology, but frustrates and mocks anyone who allows herself to be swept beyond their apparent call for meaning to an attempt to find one (95). Similarly, in the Tractatus, Wittgenstein makes use of a Kierkegaardian mirroring strategy by contriving a mock-doctrinal work of nonsense that lures readers into taking seriously the illusion that what he is saying makes sense only to explode that illusion from 
within. Like Kafka, then, he entices us with metaphysics and theology as a way of showing us how attractive such illusions can be, how strong our tendency is to defer to the (illusory) authority of what we take to be meaningful philosophical positions, and, finally, how to avoid their sway.

\section{Rootedness and Reaching}

The complexity of the word "Gleichnis" in Kafka's title thus carries over into the treatment of the different problems of outlook and confusions about language (poetic and ordinary) that Kafka offers in his parable. Kafka's play with the range of figurative, literal, instrumental, spiritual, and parabolic understandings and misunderstandings of his inscrutable cast of characters allows him to present his readers not with a single mirror in which to see ourselves and our linguistic and spiritual confusion but with a number of mirrors. ${ }^{5}$ The ending with which he leaves us is frayed, inconclusive, and open to continued debate and commentary in spite of its snappy punch line. Part of the joke is, of course, that no one really has the last word here.

Both Wittgenstein and Kafka use nonsense (which, for Wittgenstein, is not Gleichnis-not likeness, not simile) and Gleichnis (which in Kafka's work is not entirely unlike Wittgenstein's nonsense put to literary use) in their efforts to offer a picture of our everyday struggles with the mysteries of life and language and to depict a modern human condition characterized by deep and inherently frustrated yearning for truth, redemption, and ever-elusive answers. In a letter to his friend Max Brod, Kafka describes himself as a man whose feet are rooted in the world (and Word) of an infertile and conservative religious past from which he yearns to be free. His forelimbs, however, are free to reach into the heights above him. Although they find nothing firm to grasp, in their desperate waving about, he finds what he calls "inspiration" (337). Kafka's description of his simultaneous rootedness in the world and yearning for a fabulous Beyond points not only to the rooted "stuckness" that is the cause of his despair, but also to the literary creativity that his despair awakens - the inspiration to tell about something new, something "modern" perhaps, in stories that convey the strangeness, mechanization, pain, and beauty of this world and the longing to be free of it, the longing to give oneself over to another realm in the way one can only give oneself over to literature or death. Kafka finds transformative creative expression in his very pessimism about the possibility of transformation. Against such pessimism, Wittgenstein - who in the Tractatus still holds out a measure of hope for the redemptive possibilities of personal changes (whether they be the momentary epiphanic revelations he calls seeing the world sub specie aeternitatis or a more enduring conversion to "seeing the world aright") — claims that the coincidence of ethics and aesthetics occasions the transformative value of literature, for it is in literature that the experience of the ethical is expressed most compellingly as narrative enlivened by nonsense. ${ }^{6}$

\section{Harvard University}

\footnotetext{
${ }^{5}$ Conant uses this Kierkegaardian mirror analogy in his discussions of changes, from the Tractatus to the Investigations, in Wittgenstein's notions about therapeutic solution (see, most recently, "What 'Ethics' in the Tractatus Is Not").
} 


\section{Works Cited}

Adorno, Theodor. "Notes on Kafka.” Prisms. Cambridge: MIT Press, 1993. 243-71. Print.

Alter, Robert. Necessary Angels: Tradition and Modernity in Kafka, Benjamin, and Scholem. Cambridge: Harvard UP, 1991. Print.

Benjamin, Walter. "Some Reflections on Kafka." Illuminations. Trans. Harry Zohn. New York: Schocken Books, 1968. 141-46. Print.

Bramann, Jorn K. "Kafka and Wittgenstein on Religious Language." Sophia 14. 3 (1975): 1-9. Print.

Cahill, Kevin M. The Fate of Wonder: Wittgenstein's Critique of Metaphysics and Modernity. New York: Columbia UP, 2011. Print.

Conant, James. "Elucidation and Nonsense in Frege and the Early Wittgenstein." The New Wittgenstein. Ed. Alice Crary and Rupert Read. London: Routledge, 2000. 174-217. Print.

. "Kierkegaard, Wittgenstein and Nonsense." Pursuits of Reason: Essays in Honor of Stanley Cavell. Ed. Ted Cohen, Paul Guyer and Hilary Putnam. Lubbock: Texas Tech UP, 1993. 195-224. Print.

. "Mild Mono-Wittgensteinianism.” Wittgenstein and the Moral Life: Essays in Honor of Cora Diamond. Ed. Alice Crary. Cambridge: MIT Press, 2007. 31-142. Print.

_ . "Must We Show What We Cannot Say?" The Senses of Stanley Cavell. Ed. R. Fleming and M. Payne. Lewisburg: Bucknell UP, 1989. 242-83. Print.

"Putting Two and Two Together: Wittgenstein, Kierkegaard, and the Point of View for Their Work as Authors.” The Grammar of Religious Belief. Ed. D.Z. Phillips. London: Macmillan, 1994. 248-331. Print.

. "Throwing Away the Top of the Ladder." The Yale Review 79 (1991): 328-64. Print.

"What 'Ethics' in the Tractatus Is Not." Religion and Wittgenstein's Legacy. Ed. D.Z. Phillips and Mario von der Ruhr. London: Ashgate, 2005. 39-88. Print.

Conant, James, and Cora Diamond. "On Reading the Tractatus Resolutely: Reply to Meredith Williams and Peter Sullivan.” Wittgenstein's Lasting Significance. Ed. Max Kölbel and Bernhard Weiss. London: Routledge, 2004. 46-98. Print.

Rileggere Wittgenstein. Ed. Piergiorgio Donatelli. Roma: Carocci editori, 2010. Print.

Corngold, Stanley. Lambent Traces. Princeton: Princeton UP, 2004. Print.

Crary, Alice, ed. Wittgenstein and the Moral Life: Essays in Honor of Cora Diamond. Cambridge: MIT Press, 2007. Print.

Crary, Alice, and Rupert Read, eds. The New Wittgenstein. London: Routledge, 2000. Print.

Diamond, Cora. "Ethics, Imagination and the Method of Wittgenstein's Tractatus." The New Wittgenstein. Ed. Alice Crary and Rupert Read. London: Routledge, 2000. 149-73. Print.

"Introduction to 'Having a Rough Story About What Moral Philosophy Is." The Literary Wittgenstein. Ed. John Gibson and Wolfgang Huemer. London: Routledge, 2004. 127-32. Print.

The Realistic Spirit: Wittgenstein, Philosophy and the Mind. Cambridge: MIT Press, 1991. Print.

"Secondary Sense." The Realistic Spirit: Wittgenstein, Philosophy and the Mind. Cambridge: MIT Press, 1991. 225-42. Print.

"Wittgenstein on Religious Belief: The Gulfs Between Us." Religion and Wittgenstein's Legacy. Ed. D.Z. Phillips and Mario von der Ruhr. London: Ashgate, 2005. 199-38. Print.

Donatelli, Piergiorgio. "The Problem of 'The Higher' in Wittgenstein's Tractatus." Religion and Wittgenstein's Legacy. Ed. D.Z. Phillips and Mario von der Ruhr. London: Ashgate, 2005. 11-38. Print.

Fischer, Michael. "Wittgenstein as a Modernist Philosopher." Philosophy and Literature 17 (1993): 279-85. Print.

Friedlander, Eli. Signs of Sense: Reading Wittgenstein's Tractatus. Cambridge: Harvard UP, 2001. Print.

${ }^{6}$ I would like to thank Cora Diamond, Nancy Ruttenburg, Louise Hornby, Lanier Anderson, Bluma Goldstein, and Hent de Vries for their helpful comments on earlier versions of this essay. I am also grateful to the members of the Andrew W. Mellon Fellowship of Scholars in the Humanities at Stanford University for an invaluable discussion of these issues. 
Gibson, John, and Wolfgang Huemer. The Literary Wittgenstein. London and New York: Routledge, 2004. Print.

Kafka, Franz. Briefe 1902-1924. Frankfurt am Main: S. Fischer Verlag, 1958. Print. "Von den Gleichnissen." Web. <http://gutenberg.spiegel.de/bach/161/18.>

Kermode, Frank. The Genesis of Secrecy: On the Interpretation of Narrative. Cambridge: Harvard UP, 1979. Print.

Kremer, Michael. "The Purpose of Tractarian Nonsense.” NOÛS 35.1 (2001): 39-73. Print.

Landy, Joshua. How to Do Things with Fictions. New York: Oxford UP, 2012. Print.

LeMahieu, Michael. "Nonsense Modernism: The Limits of Modernity and the Feelings of Philosophy in Wittgenstein's Tractatus." Bad Modernisms. Ed. Douglas Mao and Rebecca L.Walkowitz. Durham: Duke UP, 2006. 68-93. Print.

Monk, Ray. Ludwig Wittgenstein: The Duty of Genius. New York: Penguin Books, 1991. Print.

Mulhall, Stephen. “Coda: Wittgenstein's Beetle.” Wittgenstein's Private Language: Grammar, Nonsense, and Imagination in Philosophical Investigations \$\$243-315. 133-43. Print.

. The Wounded Animal: J.M. Coetzee Eं the Difficulty of Reality in Literature E Philosophy. Princeton and Oxford: Princeton UP, 2009. Print.

North, Michael. "Translation, Mistranslation and the Tractatus." Reading 1922: A Return to the Scene of the Modern. New York: Oxford UP, 1999. 31-64. Print.

Perloff, Marjorie. Wittgenstein's Ladder: Poetic Language and the Strangeness of the Ordinary. Chicago and London: U of Chicago P, 1996. Print.

Read, Rupert, and Matthew A. Lavery. Beyond the Tractatus Wars. New York: Routledge, 2011. Print.

Ricketts, Thomas. "Pictures, Logic, and the Limits of Sense in Wittgenstein's Tractatus." The Cambridge Companion to Wittgenstein. Ed. Hans Sluga and David Stern. Cambridge: Cambridge UP, 1996. 59-99. Print.

Schuman, Rebecca. "Kafka's Verwandlung, Wittgenstein's Tractatus, and the Limits of Metaphorical Language.” Modern Austrian Literature 44.3-4 (2011): 19-32. Print.

Sokel, Walter. The Myth of Power and the Self: Essays on Franz Kafka. Detroit: Wayne State UP, 2002. Print.

Stern, David and Béla Szabados, eds. Wittgenstein Reads Weininger. Cambridge: Cambridge UP, 2004. Print.

Winch, Peter. "Discussion of [Norman] Malcolm's Essay." Wittgenstein: A Religious Point of View? Ed. Peter Winch. London: Routledge, 1993. 96-136. Print.

Wittgenstein, Ludwig. Briefe an Ludwig von Ficker. Ed. G.H. von Wright. Salzburg: Otto Müller Verlag, 1969. Print.

. "A Lecture on Ethics." Philosophical Occasions, 1912-1951. Ed. James Klagge and Alfred Nordmann. Indianapolis: Hackett Publishing Company, 1993. 37-44. Print.

. "Letters to Ludwig Ficker." Wittgenstein: Sources and Perspectives. Ed. C.G. Luckhardt. Ithaca: Cornell UP, 1979. 82-98. Print.

Ludwig Wittgenstein and the Vienna Circle: Conversations Recorded by Friedrich Waismann. Ed. B.F. McGuinness. Oxford: Blackwell, 1979. Print.

Philosophical Investigations. Trans. G.E.M. Anscombe. New York: Macmillan Publishing Co., 1953. Print.

. Tractatus Logico-Philosophicus. Trans. C.K. Ogden. London: Routledge and Kegan Paul Ltd., 1933. Print 